\title{
The influence of humic acids on desalination process with the use of electrodialysis
}

\author{
Martyna Grzegorzek ${ }^{1, *}$, and Katarzyna Majewska-Nowak ${ }^{1}$ \\ ${ }^{1}$ Wrocław University of Science and Technology, Department of Environmental Engineering, \\ Wybrzeże Stanisława Wyspiańskiego 27, 50-370 Wrocław, Poland
}

\begin{abstract}
With every year amount of drinking water in the world becomes smaller. One of the possible way to solve the problem with water scarcity is desalination. The aim of this paper is to evaluate the use of electrodialysis for salt removal in the presence of organic matter. During the tests installation PCCell BED-1-System was applied. Desalination was conducted with the use of standard ion-exchange membranes. The treated solutions contained 0.5 and $1 \mathrm{~g} \mathrm{NaCl} / \mathrm{dm}^{3}$. The solution poured into a diluate chamber was also supplemented with humic acids (concentration amounted to 5,10 and $15 \mathrm{mg} / \mathrm{dm}^{3}$ ). The current intensity was equal to $0.11 \mathrm{~A}$ (current density equal to $1.72 \mathrm{~mA} / \mathrm{cm}^{2}$ ). The process was terminated when voltage reached $24 \mathrm{~V}$. During the tests conductivity, colour and voltage was monitored. Also specific electrical energy demand (EC) was calculated. It has been found that electrodialysis can be used as an effective method for salt removal. In most cases conductivity was reduced by approximately $90 \%$. The main factor which influenced EC and process duration was mineral salt content. Besides, it has been observed that organic matter had a slight impact on the process course.
\end{abstract}

\section{Introduction}

Humic acids (HA's) are organic matter common in soils, sediments and natural water. They are macromolecules which comprise humic substances. They can be described as polydispersed, colloidal and amorphous organic compounds [1]. Characteristic for HA's is that they are insoluble in acidic media, soluble in alkaline solutions and partially soluble in water. They cause deterioration of water colour and taste. The content of humic acids ranges from $20 \mu \mathrm{g} / \mathrm{dm}^{3}$ (in groundwater) to $30 \mathrm{mg} / \mathrm{dm}^{3}$ (in surface water) [2]. Also, it is worth to know that in natural water and soil they constitute a major part of DOC (dissolved organic carbon) [2-5].

Humic acids contain different functional groups. The type of these groups is determined by many factors, i.e. climate, origin, environmental conditions or age. The majority of this group are attributed to carboxylic acid or phenol functional groups [4].

It is worth to remember about that HA's are THM's (trihalomethanes) precursors. During the disinfection and chlorination, they may create carcinogenic and very toxic substances [5].

*Corresponding author: martyna.grzegorzek@pwr.edu.pl 
Desalination means the removal of dissolved substances (like salts) from brackish, treated wastewater or seawater. The majority of Earth's surface $(71 \%)$ is covered by water. But only $3 \%$ of total water content can be used as drinking water and $0.3-0.8 \%$ of this amount has a form of liquid, fresh water. Considering water salinity, we can divide water into three categories. Seawater is characterised by the content of total dissolved solids (TDS) equal to $35000 \mathrm{mg} / \mathrm{dm}^{3}$. In brackish water (medium-salinity) TDS concentration is about $1000-15000 \mathrm{mg} / \mathrm{dm}^{3}$, whereas in fresh water (low-salinity) TDS content is not higher than $500 \mathrm{mg} / \mathrm{dm}^{3}[6-8]$.

It is important to remember that development of our civilisation resulted in reducing the water resources. It has been estimated that even 1.2 billion people may have problem with access to fresh water [5]. The current demand on potable water reached about 4500 billion $\mathrm{m}^{3}$. It has been estimated that need for drinking water can increase about 53\% till 2030 [9]. One of the possible way to overcome the problem with water scarcity is the salt water desalination. The significant growth of desalination market was noticed in the mid-1900s. The volume of desalinated water in 2016 reached value equal to 60 million $\mathrm{m}^{3} /$ day (the global scale) and in USA the amount of desalinated water reached 4.9 million $\mathrm{m}^{3} /$ day [10].

Various methods can be used for water desalination, e.g. thermal processes like distillation or evaporation. But they have disadvantages like high energy consumption and large gases emission what leads to greenhouse effect. Among others for these reasons membrane processes became more popular. High desalination efficiency, lack of necessity of chemicals use, space and energy saving and ease of operation are the main advantages of membrane techniques [11] Besides, when the salt content is lower than $5 \mathrm{~g} / \mathrm{dm}^{3}$ the membrane processes (i.e. electrodialysis, ED) are especially recommended for salt removal [12].

One of the advantages of electrodialysis is that it allows to achieve high feed recovery in comparison with distillation or other membrane techniques. It also should be noticed that ED does not need expanded pretreatment, because membrane scaling (one of the ED obstacles) can be minimized by using reversal electrodialysis. The first commercial installation consisted of electrodialysis was constructed in 1950s [12-14]. In this process ions migrate through the ion-exchange membranes and the potential difference is driving force. Anions migrate to the anode and cations are transported to the cathode. The cations can be transferred through the cation-exchange membranes but they cannot migrate through the anion-exchange membranes. The opposite situation occurs in case of anions. As the results two streams are formed - diluate and concentrate. ED is used for salt production, drinking water production, recovery of useful materials from effluents and industrial effluent treatment, whey demineralization, fruit juice deacidification or boiler water production. Also, it has been noticed that ED is more efficient economically when the salt content is low (not higher than 0.5\%) in comparison with pressure-driven processes. However, when the content of dissolved solids is very high (about $30 \mathrm{~g} / \mathrm{dm}^{3}$ ) ED can also be successfully used for desalination $[6,9,12,15-16]$.

The aim of this paper was to evaluate the possibility of electrodialysis use for desalination process in the presence of organic matter.

\section{Methods and materials}

\subsection{Installation and membranes}

The experiments were conducted with the use of electrodialytic installation PC Cell Bed-1-System. The installation operated in a batch mode. The maximum value of current intensity which can be obtained with the use of this installation was equal to $5 \mathrm{~A}$. The 
membrane stack was made of 11 cation-exchange membranes (PC-SK) and 10 anionexchange (PC-SA) membranes. Each membrane had a surface area equal to $64 \mathrm{~cm}^{2}$. The volume of diluate and concentrate amounted to $2 \mathrm{dm}^{3}$ (each). As an electrode solution $0.05 \mathrm{~mol} \mathrm{NaCl} / \mathrm{dm}^{3}$ was used. Diluate, concentrate and electrode solution circulated in three independent circulation loops - the flow rate of each solution was equal to $\pm 90 \mathrm{dm}^{3} / \mathrm{h}$. The value of flow rate corresponded with the linear liquid velocity of $6.25 \mathrm{~cm} / \mathrm{s}$.

Current intensity during the ED process had a constant value - $0.11 \mathrm{~A}$, what corresponded with current density equal to $1.72 \mathrm{~mA} / \mathrm{cm}^{2}$.

The process was terminated when the voltage value reached $24 \mathrm{~V}$.

\subsection{Reagents}

Synthetic solutions were used during the experiments. They were prepared based on distilled water. They were made of mineral salt - sodium chloride $(\mathrm{NaCl}$, molar mass $58.5 \mathrm{~g} / \mathrm{mol}$ ). The salt concentration amounted to 0.5 and $1 \mathrm{~g} \mathrm{NaCl} / \mathrm{dm}^{3}$. Solution poured into diluate tank also contained organic matter - humic acids (HA) at dosages of 5, 10 and $15 \mathrm{mg} / \mathrm{dm}^{3}$. Colour of solutions was equal to 25,50 and $75 \mathrm{mg} \mathrm{Pt} / \mathrm{dm}^{3}$, respectively.

\subsection{Methodology}

Conductivity and colour were measured during the tests. The conductivity was monitored with the use of conductometer Elmetron CC-411. The measurement error was equal to $\pm 0.25 \%$. Colour was determined with the use of spectrophotometer Hitachi U-1900. Wavelength during the measurements was equal to $350 \mathrm{~nm}$ and the calibration curve allowed to express the absorbance as colour (in $\mathrm{mg} \mathrm{Pt} / \mathrm{dm}^{3}$ ) and the accuracy of measurement reached $\pm 0.2 \%$.

Also, in every $5 \mathrm{~min}$. value of voltage was monitored. In the next step these voltage values allowed to calculate the specific electrical energy demand (EC). The specific electrical energy demand was estimated with the equation below:

$$
E C=\frac{I \int_{0}^{t} U d t}{V_{d}}
$$

where: EC - specific electrical energy demand $\left(\mathrm{kWh} / \mathrm{m}^{3}\right)$, I - current intensity (A), $\mathrm{U}$ - voltage $(\mathrm{V}), \mathrm{V}_{\mathrm{d}}$ - volume of the diluate $\left(\mathrm{m}^{3}\right), \mathrm{t}$ - process duration $(\mathrm{h})$.

\section{Results}

\subsection{Conductivity}

The variation of conductivity with time is presented in Fig. 1. 


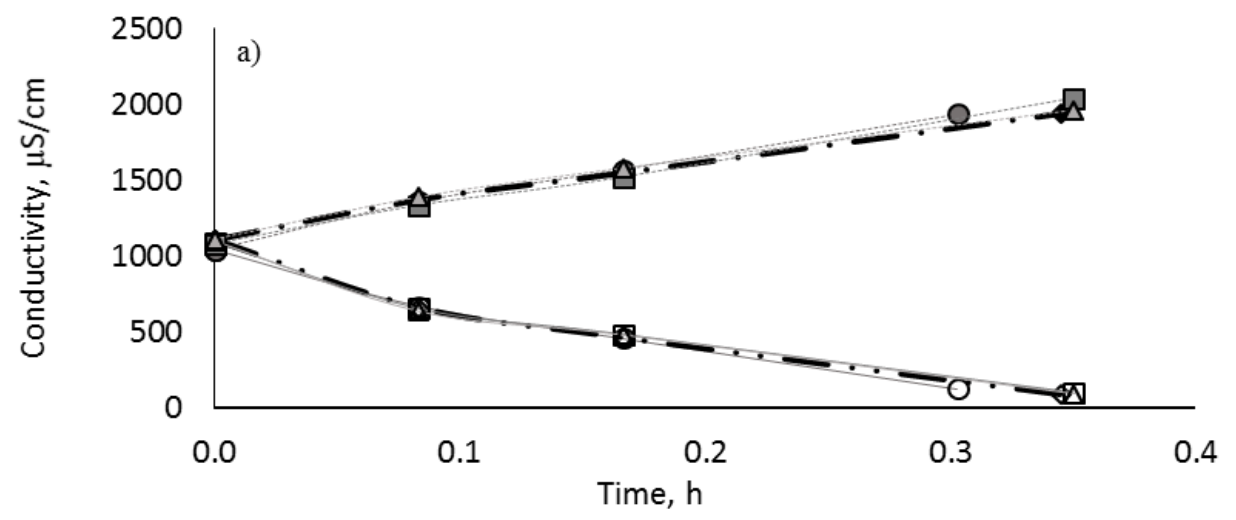

- diluate- $0.5 \mathrm{~g} \mathrm{NaCl} / \mathrm{dm} 3$

$\longrightarrow$ diluate- $0.5 \mathrm{~g} \mathrm{NaCl} / \mathrm{dm} 3+5 \mathrm{mg} \mathrm{HA} / \mathrm{dm} 3$

口- diluate- $0.5 \mathrm{~g} \mathrm{NaCl} / \mathrm{dm} 3+10 \mathrm{mg} \mathrm{HA} / \mathrm{dm} 3$

$\Delta$ diluate- $0.5 \mathrm{~g} \mathrm{NaCl} / \mathrm{dm} 3+15 \mathrm{mg} \mathrm{HA} / \mathrm{dm} 3$

concentrate- $0.5 \mathrm{~g} \mathrm{NaCl} / \mathrm{dm} 3$

$\longrightarrow$ concentrate- $0.5 \mathrm{~g} \mathrm{NaCl} / \mathrm{dm} 3+5 \mathrm{mg} \mathrm{HA} / \mathrm{dm} 3$

- concentrate- $0.5 \mathrm{~g} \mathrm{NaCl} / \mathrm{dm} 3+10 \mathrm{mg} \mathrm{HA} / \mathrm{dm} 3$

$\Delta$ concentrate- $0.5 \mathrm{~g} \mathrm{NaCl} / \mathrm{dm} 3+15 \mathrm{mg} \mathrm{HA} / \mathrm{dm} 3$

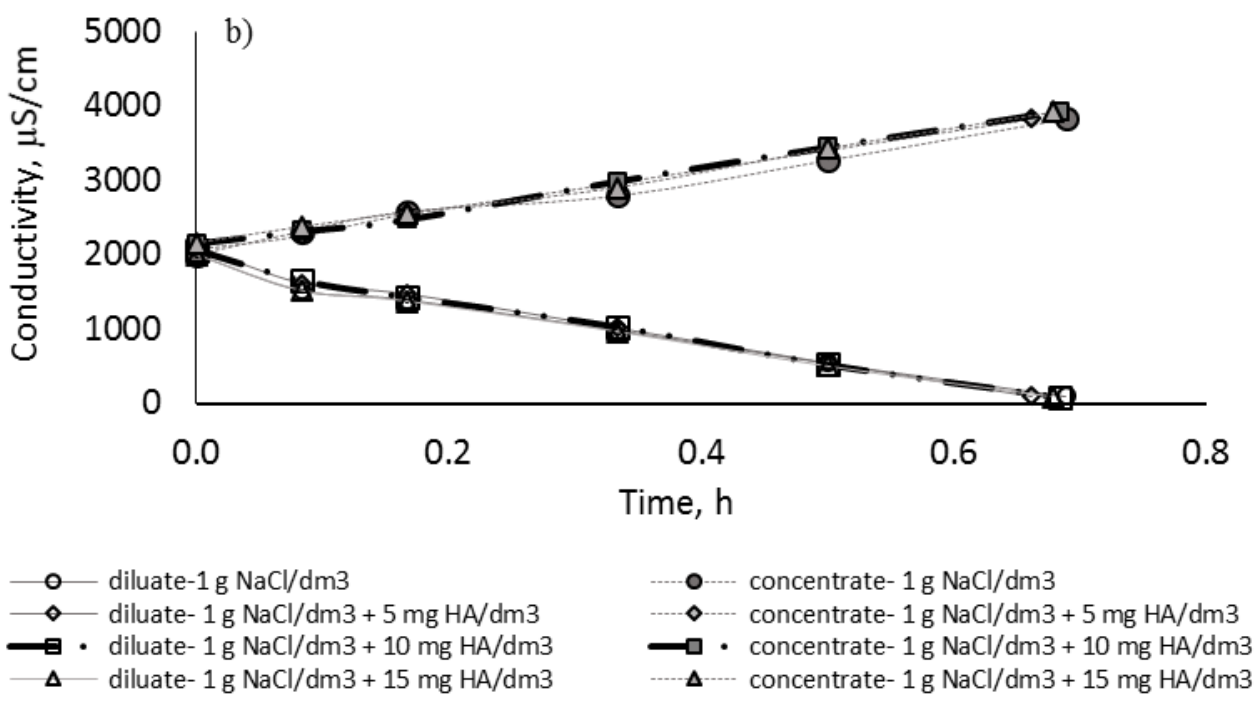

Fig. 1. Conductivity versus ED operational time for diluate and concentrate at various humic acids concentration: a) $\mathrm{C}_{0}=0.5 \mathrm{~g} \mathrm{NaCl} / \mathrm{dm}^{3}$; b) $\mathrm{C}_{0}=1.0 \mathrm{~g} \mathrm{NaCl} / \mathrm{dm}^{3}$; current density $=1.72 \mathrm{~mA} / \mathrm{cm}^{2}$.

It has been observed that the initial conductivity of solutions containing $0.5 \mathrm{~g} \mathrm{NaCl} / \mathrm{dm}^{3}$ amounted to $1042-1110 \mu \mathrm{S} / \mathrm{cm}$. The diluate conductivity decreased to $93.5-131 \mu \mathrm{S} / \mathrm{cm}$ at the end of ED process. The best results occurred when HA's content amounted to $5 \mathrm{mg} / \mathrm{dm}^{3}$ and the worst effect was observed when solution without of organic matter dosage was treated.

The initial conductivity increased to $2000-2110 \mu \mathrm{S} / \mathrm{cm}$ when salt concentration reached $1 \mathrm{~g} \mathrm{NaCl} / \mathrm{dm}^{3}$. The obtained results showed similar trend to that for solutions containing $0.5 \mathrm{~g} \mathrm{NaCl} / \mathrm{dm}^{3}$ - the final conductivity was lowered to $87.7-104.7 \mu \mathrm{S} / \mathrm{cm}$. When the HA's content was equal to $5 \mathrm{mg} / \mathrm{dm}^{3}$, the results were least satisfying and the lowest conductivity was obtained when organic matter concentration reached $10 \mathrm{mg} / \mathrm{dm}^{3}$. 
The process duration was approximately $21 \mathrm{~min}$ when the salt content amounted to $0.5 \mathrm{~g} \mathrm{NaCl} / \mathrm{dm}^{3}$ and it has been noticed that process was around two times longer when $\mathrm{NaCl}$ concentration was equal to $1 \mathrm{~g} \mathrm{NaCl} / \mathrm{dm}^{3}$.

It has been observed that HA's did not have remarkable influence on process duration. The main factor which had impact on the length of the ED process was salt content. This is consistent with Faraday's law in which the amount of ionic equivalents which should be removed depends on time of the process and the current intensity.

\subsection{Desalination efficiency}

Desalination efficiency (expressed as the conductivity drop) was also calculated. The obtained results are presented in Fig. 2.

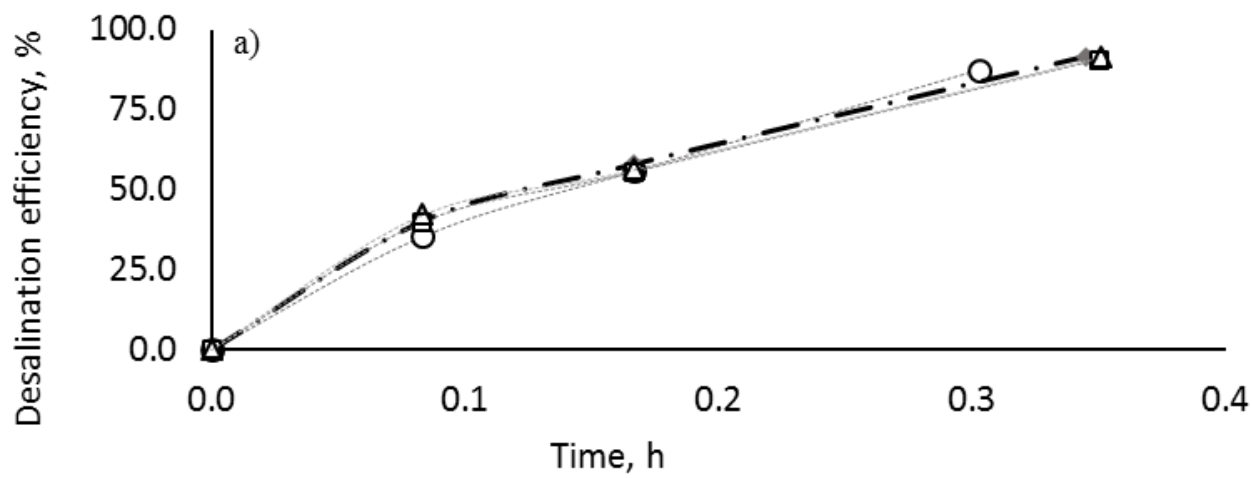

\footnotetext{
$\mathrm{O}-\mathrm{NaCl}$

․ $\mathrm{NaCl}+10 \mathrm{mgHA} / \mathrm{dm} 3$

$$
\underset{\Delta-\mathrm{NaCl}+5 \mathrm{mg} \mathrm{HA} / \mathrm{dm} 3}{\longrightarrow}-15 \mathrm{mg} \mathrm{HA} / \mathrm{dm} 3
$$
}
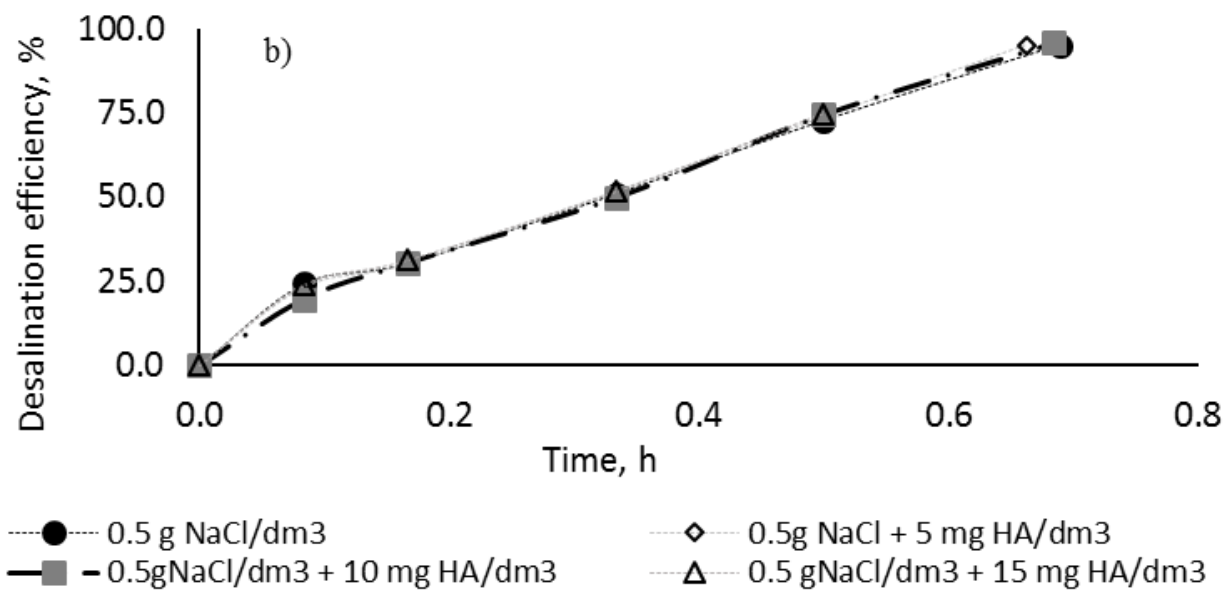

$$
\begin{array}{ll}
\diamond & 0.5 \mathrm{~g} \mathrm{NaCl}+5 \mathrm{mg} \mathrm{HA} / \mathrm{dm} 3 \\
\Delta & 0.5 \mathrm{gNaCl} / \mathrm{dm} 3+15 \mathrm{mg} \mathrm{HA} / \mathrm{dm} 3
\end{array}
$$

Fig. 2. Desalination efficiency versus $E D$ operational time at various humic acids concentration: a) $\mathrm{C}_{0}=0.5 \mathrm{~g} \mathrm{NaCl} / \mathrm{dm}^{3}$; b) $\mathrm{C}_{0}=1.0 \mathrm{~g} \mathrm{NaCl} / \mathrm{dm}^{3}$; current density $=1.72 \mathrm{~mA} / \mathrm{cm}^{2}$. 
When sodium chloride content amounted to $0.5 \mathrm{~g} \mathrm{NaCl} / \mathrm{dm}^{3}$ the desalination efficiency was very satisfying and it varied from 87.4 to $91.6 \%$. High desalination efficiency was also obtained for solutions containing $1 \mathrm{~g} \mathrm{NaCl} / \mathrm{dm}^{3}$ - it reached about $95-95.7 \%$.

It can be stated that organic matter has a minor impact on desalination efficiency. The presence of organic matter may insignificantly enhanced the desalination efficiency. It can be caused by the ions trapping inside the expanded structure of humic acids. The second one explanation is attracting the chloride ions by the $\mathrm{Na}^{+}$ions which had been bounded to negatively charged surface of HA macroparticles. As the result desalination efficiency is apparently enhanced, however this is due to the interactions between diluate components.

\subsection{Colour}

Colour was also measured during the ED tests. It was quite obvious that colour of solutions containing only sodium chloride (regardless of $\mathrm{NaCl}$ concentration) was close to $0 \mathrm{mg} \mathrm{Pt} / \mathrm{dm}^{3}$. It allows to claim that mineral salt does not contribute in the colour intensity of the experimental samples. As it has been mentioned previously, when HA content amounted to 5,10 and $15 \mathrm{mg} / \mathrm{dm}^{3}$, the initial colour of diluate was equal to around 25,50 and $75 \mathrm{mg} \mathrm{Pt} / \mathrm{dm}^{3}$, respectively.

During the ED process depletion of diluate colour was observed. The final percentage colour reduction (at the end of electrodialysis) is shown in Fig. 3.

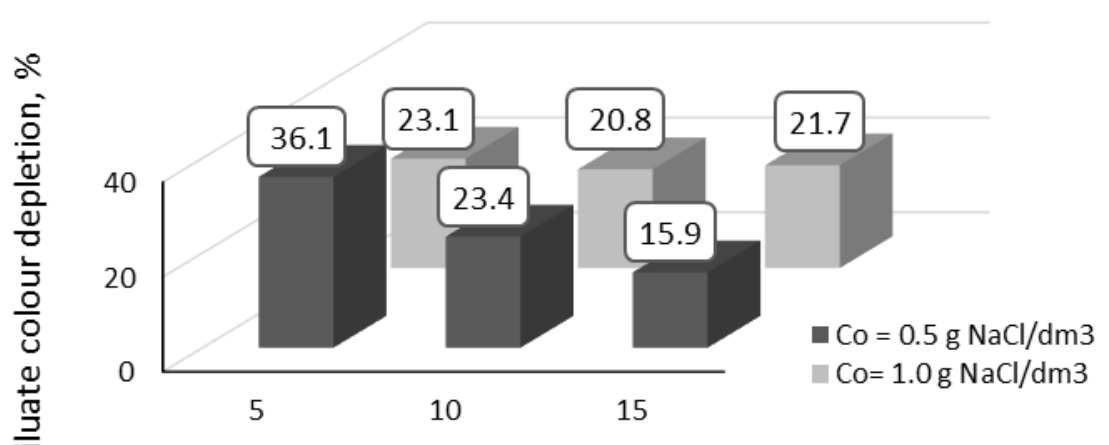

Humic acids concentration, $\mathrm{mg} / \mathrm{dm}^{3}$

Fig. 3. Depletion of diluate colour versus HA concentration; current density $=1.72 \mathrm{~mA} / \mathrm{cm}^{2}$.

It has been observed that diluate colour decreased in the range of $15.9-36.1 \%$ (average $25.1 \%$ ), when the $\mathrm{NaCl}$ content was equal to $0.5 \mathrm{~g} \mathrm{NaCl} / \mathrm{dm}^{3}$ and in the range of $20.8-23.1 \%$ (average $21.9 \%$ ), when salt concentration amounted to $1 \mathrm{~g} \mathrm{NaCl} / \mathrm{dm}^{3}$. At the same time it has been noticed that concentrate was deprived of organic matter and its colour was close to $0 \mathrm{mg} \mathrm{Pt} / \mathrm{dm}^{3}$ in the course of ED process. This observation allows to state that HAs did not migrate from diluate to concentrate chamber. It can be assumed that colour depletion was caused by the deposition of humic acid macroparticles on membrane surface.

\subsection{Specific electrical energy demand}

Energy consumption is a crucial parameter for potential end-users, thus the specific electrical energy demand (EC) was calculated during the ED process. The EC was calculated with the use of equation (1). 
The calculated energy consumption for various composition of treated solutions is presented in Fig. 4.

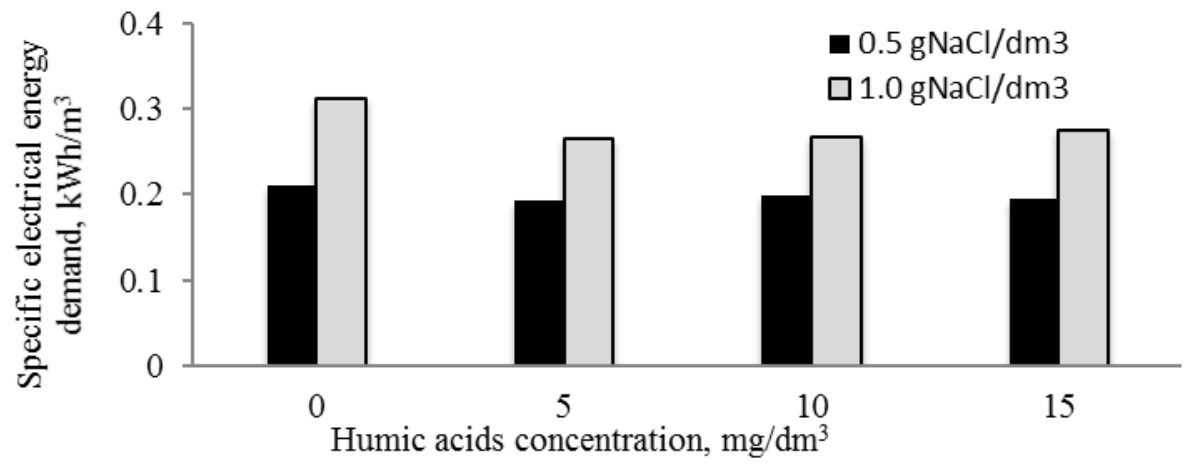

Fig. 4. Specific electrical energy demand versus humic acid and $\mathrm{NaCl}$ content; current density $=1.72$ $\mathrm{mA} / \mathrm{cm}^{2}$.

It has been observed that the specific electrical energy demand was lower about $25.8-32.7 \%$ for solutions containing $0.5 \mathrm{~g} \mathrm{NaCl} / \mathrm{dm}^{3}$ than for solutions with $1 \mathrm{~g} \mathrm{NaCl} / \mathrm{dm}^{3}$. It has been noticed that the energy demand varied from 0.193 to $0.210 \mathrm{kWh} / \mathrm{m}^{3}$. The highest value of EC occurred without HA's addition and the lowest when concentration of HA's was equal to $5 \mathrm{mg} / \mathrm{dm}^{3}$.

ED experiments with solutions containing $1 \mathrm{~g} \mathrm{NaCl} / \mathrm{dm}^{3}$ arrived at the $\mathrm{EC}$ increased and it varied from 0.265 to $0.312 \mathrm{kWh} / \mathrm{m}^{3}$. When organic matter content was equal to $5 \mathrm{mg} / \mathrm{dm}^{3}$ EC was the lowest, whereas without HA's addition energy demand was the highest.

It has been found that in ED desalination plant with capacity equal to $2200 \mathrm{~m}^{3} /$ day and total dissolved solids content equal to $1.2 \mathrm{~g} / \mathrm{dm}^{3}$ energy demand for demineralisation was equal to $0.064 \mathrm{kWh} / \mathrm{m}^{3}$. Whereas EC for pumping reached $0.4 \mathrm{kWh} / \mathrm{m}^{3}$, the total energy consumed during the process was calculated as $0.464 \mathrm{kWh} / \mathrm{m}^{3}$ [17]. This order of magnitude of energy consumption was comparable with EC calculated during experiments described in this paper.

It can be stated that humic acids had a slight impact on energy consumption. Macroparticles of humic acids deposited on the membranes surface may lead to the increase of membrane resistance, as well as the resistance of ED stack. As the result more energy is needed to conduct the desalination process.

\section{Conclusions}

It can be stated that electrodialysis can be used as an effective method for water desalination. The conductivity drop was close to $90 \%$, regardless of the mineral salt content in experimental solutions. Besides, it has been observed that humic acids have a minor influence on desalination efficiency and process duration. It was worth to notice that the major factor which had impact on process duration was $\mathrm{NaCl}$ content.

The specific electrical energy demand (EC) was much higher for solutions containing $\mathrm{g} \mathrm{NaCl} / \mathrm{dm}^{3}$ in comparison to solutions with low salt content $\left(0.5 \mathrm{~g} \mathrm{NaCl} / \mathrm{dm}^{3}\right)$. The presence of organic matter (in a form of humic acids, HAs) in the treated solutions had a slight impact on EC value. It can be predicted that HAs are deposited on the membrane surface, thus increasing the resistance of ED stack. As a result more energy is needed to conduct the desalination process. 
The deposition of HA particles on membrane surface was supported by diluate colour depletion. Concomitantly, the colour of concentrate remained relatively stable and it was close to $0 \mathrm{mg} \mathrm{Pt} / \mathrm{dm}^{3}$ during the ED process.

It is recommended to use the electrodialysis as final treatment preceded by other pretreatment processes. Such approach allows to reduce costs of the electrodialysis and protect membranes against fouling (as a result membranes lifespan will be improved).

The financial support of the Faculty of Environmental Engineering (Wroclaw University of Science and Technology, grant no. 0402/0080/16) is greatly appreciated.

\section{References}

1. S. Zhang, L. Yuan, W. Li, Z. Lin, Y. Li, S. Hu, B. Zhao, Chemosphere 166, 334-342 (2017)

2. M. Wang, L. Liao, X. Zhang, Z. Li, Appl Clay Sci. 67-68, 164-168 (2012)

3. Klučáková, React. Funct. Polym. 109, 9-14 (2016)

4. B.A. Gomes de Melo, F. Lopes Motta, M.H. Andrade Santana, Mater. Sci. Eng. C Mater. Biol. Appl. 62, 967-964 (2016)

5. K. Szymański, A.W. Morawski, S. Mozia, Chem. Eng. J. 305, 19-27 (2016)

6. M. Sadrzadeh, T. Mohhamadi, Desalination 221, 440-447 (2008)

7. A.H. Galama, M. Saakes, H. Bruning, H.H.M. Rijnaarts, J.W. Post, Desalination 342, 61-69 (2014)

8. M.A. Alghoul, P. Poovanaesvaran, K. Sopian, M.Y. Sulaiman, Renew. Sust. Energ. Rev. 13, 2661-2667 (2009)

9. E.A. Abdel-Aal, M.E. Farid, F.S.M. Hassan, A.E. Mohamed, Egypt. J. Pet. 24, 71-75 (2015)

10. J.R. Ziolkowska, R. Reyes, J. Environ. Manage. 167, 15-22 (2016)

11. K. Wang, A.A. Abdalla, M.A. Khaleel, N. Hilal, M.K. Khraisheh, Desalination 401, 190-205 (2017)

12. K. Ghyselbrecht, M. Huygebaert, B. Van der Bruggen, R. Ballet, B. Meesschaert

13. K. Tado, F. Sakai, Y. Sano, A. Nakayama, Desalinaiton 378, 60-66 (2016)

14. B.A. Qureshi, S.M. Zubair, Desalination 394, 195-203 (2016)

15. Ch. Xue, Q. Chen, Y.-Y. Liu, Y.-L. Yang, D. Xu, L. Xue, W.-M. Zhang, J. Membrane Sci. 493, 28-36 (2015)

16. L.J. Banasiak, T.W. Kruttschnitt, A.I. Schäfer, Desalination 205, 38-46 (2007)

17. S. Lahnid, M. Tahaikt, K. Elaroui, I. Idrissi, M. Hafsi, I. Laaziz, Z. Amor, F. Tiyal, A. Elmidaoui, Desalination 230, 213-219 (2008) 